\title{
FEASIBLE EVALUATION OF PQ BYPASS RESULTS WITH DUPLEX ULTRASOUND
}

\author{
Aigars Lācis ${ }^{1,2, \#}$, Natālija Ezīte ${ }^{1}$, Jānis Šavlovskiș ${ }^{1,3}$, Indulis Kukuliș ${ }^{1}$, \\ Roberts Rumba ${ }^{1,2}$, Eva Striḳe ${ }^{1,2}$, Edgars Zellāns ${ }^{1,3}$, Inguna Luūlaka ${ }^{1}$, \\ and Dainis Krieviņšs ${ }^{1,3}$

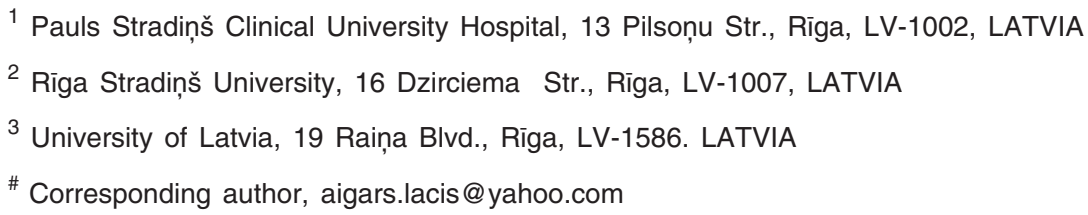

Contributed by Dainis Krievinš

\begin{abstract}
Patients with peripheral arterial disease (PAD) have substantially impaired health-related quality of life (HR-QoL). Chronic lower limb ischaemia due to the atherosclerotic occlusion of infra-inguinal arteries is one of the most important causes of invalidity among smokers over the age of fifty. Historically, these lesions were treated by open bypass surgery. Less invasive endovascular revascularisation methods are available to treat short lesions, while treatment of long lesions are lacking. Fully endovascular trans-venous femoro-popliteal bypass (PQ Bypass, Inc., Sunnyvale, CA, USA) to treat long femoral lesions has been developed recently. The objective of the study was to evaluate duplex ultrasound (DUS) as a tool to follow up patients after PQ bypass procedure. A prospective clinical study was conducted at one clinical site. DUS of treated arteries and femoral vein was performed before the procedure, 30 days, 6 months, and 12 months in follow-up period by 2 independent radiologists. Ankle-brachial index (ABI) evaluation was performed at all visits. Thirty-five patients (35 limbs) treated with $P Q$ bypass were enrolled in the study. Median age was 63.6 years (ranged 50 to 87 years). There was 100\% successful evaluation of all patients at all clinical visits available. Deviation of the DUS results was found within the accepted standard limit between two radiologists. Twelve months after the $P Q$ procedure, 28 (80.0\%) $P Q$ stent-grafts were still functioning without DUS signs of stenosis, while seven (20.0\%) limbs experienced varying degrees of stent malfunction. $P Q$ stent-graft occlusion was detected in five (14.3\%) - 1 (2.9\%) patients at one-month follow-up, 3 (8.6\%) at six months and 1 (2.9\%) at twelve months follow-up period, respectively. $P Q$ stent-graft proximal junction stenosis was detected in one patient (2.9\%) at six months and distal junction stenosis in one patient $(2.9 \%)$ at twelve months follow-up, respectively. Despite of graft occlusion found with DUS, two patients had no severe worsening of post-operative ABI. DUS is a reliable method to evaluate patients after $P Q$ bypass procedure and has higher sensitivity than $A B I$ to follow-up patients after $P Q$ procedure, especially in asymptomatic stent stenosis. Regular and timely use of DUS during the postoperative period may help to recognise potential complications and provide effective treatment..
\end{abstract}

Key words: peripheral arterial occlusive disease, stent graft, arterial bypass.

\section{INTRODUCTION}

Peripheral arterial disease (PAD) is characterised by partial or complete atherosclerotic obstruction of the arteries of the lower extremities. It is estimated that more than 200 million people have PAD worldwide, with a spectrum of symptoms from none to severe (Fowkes et al., 2013).

Prevalence and incidence of PAD are both sharply agerelated, increasing to more than $10 \%$ among patients in their 60 s and 70s. Annual incidence of PAD among men reaches 
1.7 per 1000 at the age of 40 to 54 years, 1.5 per 1000 at the age of 55 to 64, and 17.8 per 1000 at the age of 65 (Hoii et al., 2001).

Chronic lower limb ischaemia due to the occlusion of infra-inguinal arteries of atherosclerotic genesis is one of the most important causes of invalidity among smokers over the age of fifty. Patients with PAD have substantially impaired health-related quality of life (HR-QoL) (Van Hattum et al., 2011).

Intermittent claudication is the first symptom of the disease, and non-invasive measures, such as the ankle-brachial index (ABI), show that asymptomatic PAD is several times more common in the population than intermittent claudication (Aboyans et al., 2008).

It should be stressed, that in 15-20\% of cases chronic lower limb ischaemia progresses to critical limb ischaemia (CLI), characterised by rest pain, ischemic ulcers and gangrene (Criqui et al., 2015).

Historically, peripheral arterial occlusions in lower extremities were treated by open bypass surgery. Nowadays, thanks to the rapid development of technologies, different endovascular revascularisation methods are available for the treatment of femoro-popliteal arterial lesions. Stents or stent grafts are used to support the result obtained during percutaneous angioplasty.

Existing endovascular technologies have a well-documented success rate with TASC A (Trans Atlantic Inter-Societal Consensus) and TASC B lesions of femoral artery. Longer TASC C and TASC D lesions, as well as lesions with complicated and extensive calcification and chronic total occlusion of the superficial femoral artery (SFA) have a much lower success rate. Thus, new concept PQ bypass was developed to treat long lesions.

Percutaneous PQ bypass procedure is designed to treat long femoral artery lesions and to achieve the same end result as open bypass surgery (Krievins et al., 2018). A specially designed stent for this procedure, the TORUS stent graft system, is an expanded polytetrafluorethylene (ePTFE) covered self-expanding nitinol stent intended to restore blood flow in femoral artery. Regular stents were usually placed directly in the lumen of the diseased artery. In contrast, PQ bypass utilises the femoral vein as a conduit for the stent. Subsequently, deep venous thrombosis does not allow (exclude) the usage of PQ bypass for purely technical reasons. PQ procedure has not been performed in patients with haemodynamically significant stenosis of femoral vein (Fig. 1).

Nowadays evaluate duplex ultrasound (DUS) and anklebrachial index (ABI) are standard non-invasive first-line examinations in patients with PAD. No data have been reported so far on studies using DUS to evaluate PQ bypass in patients with long femoral artery occlusions (mean $37 \mathrm{~cm}$ ), as was conducted in our study. The goal of our study was to evaluate the use of DUS in post-procedural follow-up of patients after PQ bypass.

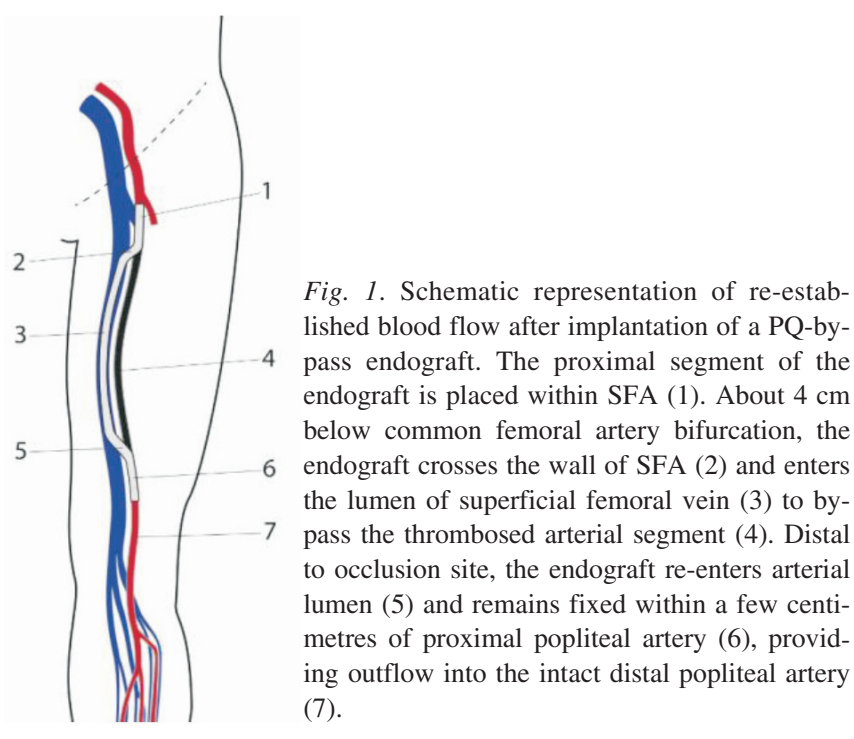

\section{PATIENTS AND METHODS}

Thirty-five patients (35 limbs) with PAD Rutherford class III and IV underwent PQ procedure for superficial femoral artery lesion at Pauls Stradiņš Clinical University Hospital (Rìga, Latvia).

The Local Ethics Committee gave approval for the study. All patients signed a consent form before the study.

Thirty-two (91.4\%) patients were males and two (8.6\%) females with median age 63.6 years (ranged 50 to 87 years).

Initial eligibility evaluation of patients prior to PQ procedure was based on computed tomography angiography (CTA) of abdominal aorta and lower extremity arteries as well as arterial and venous DUS findings.

Follow-up was done using DUS and ABI determination at 30 days, 6 months, and 12 months.

All ultrasound examinations were performed using a Phillips iU22 xMATRIX Ultrasound system with a L9-3 linear transducer. B-mode ultrasound was used to evaluate stent graft position, deformities, vein diameters, compressibility, and leg oedema. DUS was used to evaluate haemodynamics proximally and distally from the stent graft, as well as in stent, vein reflux, and flow. Peak systolic velocity (PSV), resistive index (RI), and spectral waveform were evaluated, as well as distal blood flow in the arteries of the leg.

DUS in the prospective clinical study was conducted at one clinical site by two independent radiologists. A result was accepted if the differences for inter-observer PSV measurement were less than $40 \mathrm{~cm} / \mathrm{s}$ (Winter-Warnars et al., 1996).

The ankle-brachial index (ABI) was calculated as the ratio of blood pressure at the ankle to the blood pressure in the brachium (Aboyans et al., 2012). Segmental systolic pressure measurement was performed, using an OMRON Vascular Profiling System VP-1000 (USA). 


\section{RESULTS}

Follow-up evaluation of 35 patients (35 limbs) with PQ bypass was conducted at 1, 6 and 12 months after PQ procedure in all patients. It included an assessment of the results of the Rutherford score (Rutherford et al., 2005), ABI, arterial and venous DUS.

According to TASC classification of PAD (Jaff et al., $2015)$, the study enrolled four patients $(11.4 \%)$ with TASC B lesion, 19 (54.3\%) with TASC C lesion, and 12 patients (34.3\%) with TASC D lesion, respectively.

Thirty of the study patients $(85.7 \%)$ were matched to Rutherford classification grade III, four $(11.4 \%)$ to grade IV, and one patient $(2.9 \%)$ corresponded to Rutherford grade V.

All patients underwent ABI measurement pre- and post-operatively. In four $(11.4 \%)$ patients, prior to the PQ procedure the ABI ranged from $0.4-0.49$, in ten patients $(28.6 \%)$ from $0.5-0.59$, in 13 patients $(37.1 \%$ ) from $0.6-0.69$, in six patients (17.1\%) from $0.7-0.79$, and ABI was 0.83 in one patient $(2.9 \%)$. One patient $(2.9 \%)$ with severe atherosclerosis and type 2 diabetes had ABI 1.5.

A good result of the PQ bypass during the DUS investigation is characterised by antegrade flow inside the stent-graft and retrograde flow next to the vein walls. A good PQ treatment result also is confirmed by three-phase flow inside the stent-graft and with no signs of significant stenosis or obstructions in the arterio-venous junction area of the stentgraft (Fig. 2).

As a criteria for grading the degree of arterial narrowing from the DUS, we used the ratio of pre-stenosis/stenosis, proposed by Cossman et al. (1989). A velocity ratio $<1.5$ : 1 corresponds to normal artery, a velocity ratio $1.5-2.1$ cor- responds to $25-50 \%$ arterial stenosis, the ratio $2-4.1$ corresponds to $50-75 \%$ arterial stenosis, and the ratio $4: 1$ corresponds to stenosis of artery $>75 \%$. No flow means that the artery is closed. Twelve months after the PQ procedure, 28 PQ stent-grafts $(80 \%)$ were still functioning without DUS signs of stenosis while seven limbs (20\%) experienced varying degrees of stent malfunction.

PQ stent-graft occlusion was detected in five patients $(14.3 \%)$, one $1(2.9 \%)$ at one-month follow-up, three $(8.6 \%)$ at six months and one $(2.9 \%)$ at twelve months.

PQ stent-graft proximal junction stenosis $>50 \%$ was detected in one patient $(2.9 \%)$ at six months follow-up and distal junction stenosis in one patient (2.9\%) at twelve months follow-up (Fig. 3).

In five limbs (14.3\%), including two with PQ stent-graft, previous detected stenosis and stent thrombosis developed (Fig. 4).

All patients with PQ stent-graft stenosis were asymptomatic. All patients with PQ stent thrombosis presented symptoms of acute lower limb ischaemia.

During follow-up visits of patients with documented PQ stent-graft stenosis, examination showed only a slight decrease of ABI (range 0.05 to 0.15 ) compared to the immediate post-operative result.

Despite of insignificant reduction of ABI, DUS evaluation showed significant stenosis when even ABI results failed to detect them.

The criteria for bypass stenosis detection are the same as for surgical bypasses in other studies. However, these methods cannot be compared directly because each of them has its
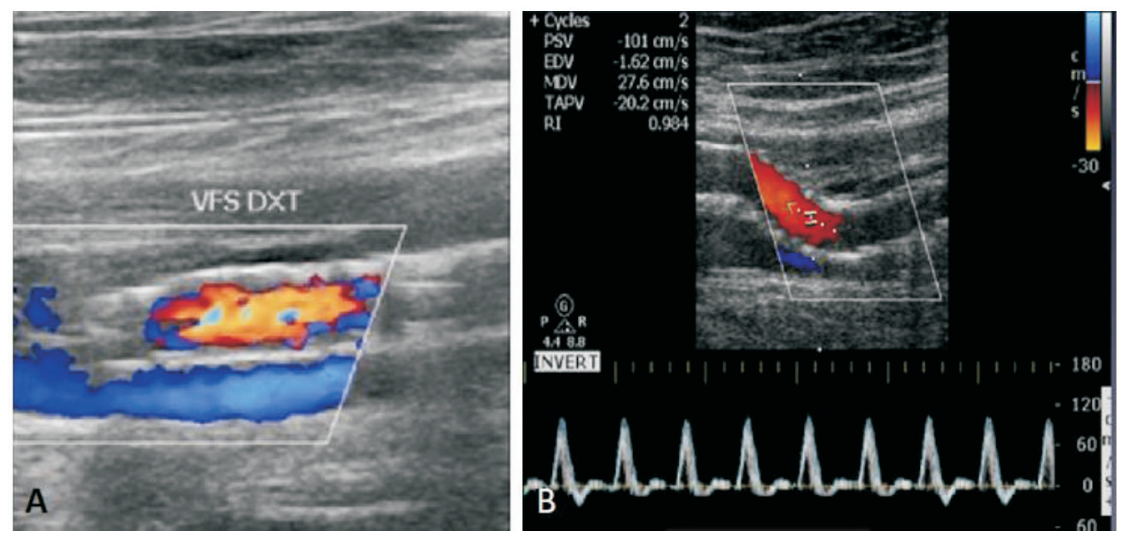

Fig. 2. (A) PQ stent-graft inside a femoral vein. (B) Fully patent $\mathrm{PQ}$ stent-graft's arterio-venous junction. The stent-graft is well defined with hyper-echoic wall. Arterial triphasic flow is observed inside the PQ stent-graft.
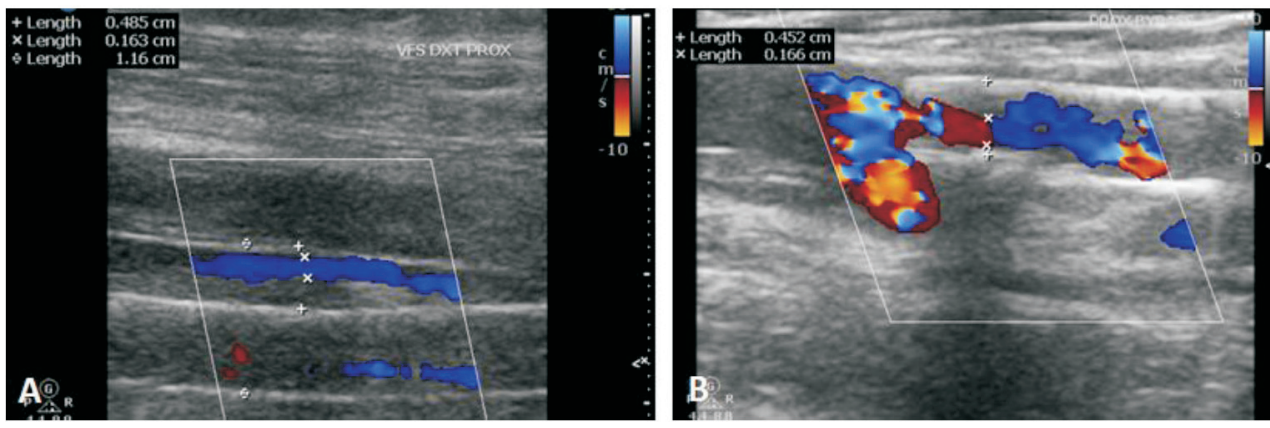

Fig. 3. DUS detects wall clot in stent, narrowing PQ stent-graft (A) and the PQ stent-graft proximal junction (B). 

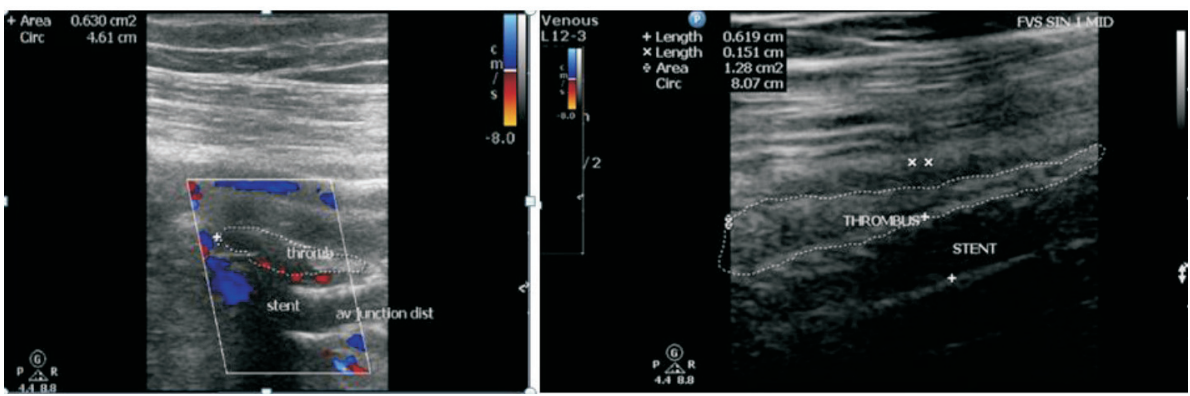

Fig. 4. PQ stent-graft thrombosis.

own indications and contraindications. The relatively high number of early complications in our study is related to the endovascular treatment of long femoral arterial occlusions (mean $37 \mathrm{~cm}$ ), which has not been effective in any of the studies available to date. Endovascular treatment does not replace classical surgical treatment. Its main advantage is the possibility of application in situations where open surgical treatment is dangerous, or even unwanted, such as infection, severe general condition of the patient, etc. Our method continues to evolve.

Subsequent treatment tactics in patients with PQ shunt thrombosis include symptomatic conservative therapy, but in cases of progression of acute limb ischaemia - open surgical revascularisation.

\section{DISCUSSION}

In 2000, the first TASC meeting recommended that TASC A lesions must be treated endovascularly, and TASC D lesions surgically, but no recommendation was given for TASC B and C lesions treatment due to lack of evidence (Dormandy et al., 2000). The BASIL trial is the only study that has compared vein bypass and angioplasty in PAD patients with CLI (Adam et al., 2005).

With improving techniques and technologies, an increasing number of cases may now be managed with endovascular procedures (Jaff et al., 2015). In practical terms, although the level of evidence is low, the initial revascularisation strategy for femoro-popliteal disease is commonly an endovascular approach, particularly for those patients with limited life expectancy (Antoniou et al., 2013).

A four-year randomised prospective comparison of percutaneous ePTFE/Nitinol self-expanding stent graft versus prosthetic femoral-popliteal bypass in the treatment of superficial femoral artery occlusive disease did not find any difference between the stent graft and synthetic surgical bypass groups in a 1- to 4-year follow-up period in patients with an average lesion length of $25+/-15 \mathrm{~cm}$ and TASC scores distributed equally from A through D (McQuade et al., 2010).

Despite lower patency in endovascular-treated TASC C/D groups, investigators are divided on whether to recommend surgery as the primary treatment for long-segment disease. TASC D patients continue to have poor prognosis compared to TASC A-C, and the patency rates for all lesion types are better compared to stenting and PTA. In terms of TASC categories, PTA and/or stenting have outcomes equal to or better than surgery for TASC A and B lesions, but fail to match surgery's patency rates in TASC C or D lesions (Surowiec et al., 2005).

Another question to which there is still no clear answer is whether endovascular treatment is applicable for patients with prolonged (more than $20 \mathrm{~cm}$ ) superficial femoral artery occlusions. Endovascular therapy to facilitate intermittent claudication and provide durable treatment options for many PAD patients with CLI, and PQ stent-graft could be one method that would help to treat these patients (Krievins et al., 2018).

Regular clinical assessments should be carried out to assess performance to the procedure done, the recurrence of symptoms and the maintenance of medical therapy. It should however be supplemented with physiological tests, first of all non-invasive. ABI and DUS have been identified as the simplest and most appropriate methods capable of reliably evaluating the results of lower limb revascularisation. It has been proven that the durability of good surgery results is closely associated with careful follow-up, which helps to detect PAD progression or stent-graft restenosis in a timely manner. $\mathrm{ABI}$ is inexpensive, minimally time consuming and it is usually used as widely as DUS (Criqui et al., 2010). An ABI of 0.90 has $75 \%$ sensitivity and $86 \%$ specificity to diagnose lower extremity artery disease) (Xu et al., 2013).

The ABI can easily be obtained during a physical investigation, calculating the ratio between the highest ankle pressure measured in the dorsalis pedis artery and anterior tibial artery on each leg and the higher of two brachial pressures. The value 0.9 corresponds to haemodynamically significant arterial obstructive disease between the aorta and the ankle (Aboyans et al., 2012).

ABI reductions by more than 0.15 in relation to the initial value obtained following the procedure indicate the occurrence of restenosis at the intervention site or newly developed disease outside the treated segment (Sobieszczyk et al., 2013).

Thus, as already shown, a change in ABI refers to changes in arterial perfusion, but does not determine its location. The extent of the reduction of the ABI when re-intervention must be performed has not been studied as yet. Some authors believe that a $20 \%$ reduction compared to the original ABI immediately after the procedure leads to a thorough 
review of DUS and symptoms. However, it must be remembered that $\mathrm{ABI}$ is not helpful in calcified and uncompressible vessels, which can falsely raise ABI by masking a drop-in ankle perfusion.

Obviously, to gain confidence that the PQ shunt works in patient undisturbed requires its visualisation.

DUS is a useful non-invasive alternative to CTA. DUS can detect and localise vascular lesions and quantify their extent and severity through velocity criteria (Vlachopoulos et al., 2015). DUS presents $85-90 \%$ sensitivity and $>95 \%$ specificity to detect stenosis $>50 \%$ (Collins et al., 2007).

Clinical studies have shown that the quality of DUS depends on the user's level of experience, and that some arterial segments may be visualised more readily than others, but it still continues to play a very important role in PAD diagnosis both before and after arterial revascularisation (Eiberg et al., 2010).

As our study results have already shown, DUS monitoring after PQ stent-graft implantation allows timely identifying even a low-grade stenosis. At this stage, repeated intervention can preserve the patency of the stent and prevent it from being occluded. This is unlike ABI, which may not be a sufficiently sensitive for assessing a low-grade stenosis, especially if the collaterals fully mask symptoms of CLI.

Early detection of stenosis or new disease after endovascular therapy may result in less complicated re-intervention to restore stent permeability and to prevent the development of acute ischaemia.

Our study group of patients included mostly claudicants with $\mathrm{ABI}>0.4$. However, even for this small CLI patient cohort, DUS was sensitive, which was actually the main aim of this research.

The small number of patients and events should be considered in the interpretation of results. Therefore, further studies are needed to better assess the potential of DUS in the assessment of PAD patients after PQ stent-graft procedure.

\section{CONCLUSIONS}

DUS and ABI are recommended methods for evaluating PQ bypass results during the follow-up period.

$\mathrm{ABI}$ determination is an objective, minimum time consuming and non-invasive investigative method to control the outcome of the PQ procedure. However, it may not be a sufficiently sensitive for assessing a low-grade stenosis, especially if the collaterals fully mask the symptoms of lower limb ischaemia.

DUS allows to accurately and timely identify even lowgrade stenosis of the PQ stent-graft.

Early detection of PQ stent-graft stenosis or new disease through the DUS may result in less complicated re-intervention to restore stent permeability and to reduce symptoms of ischaemia.

\section{REFERENCES}

Aboyans, V., Criqui, M. H., Abraham, P., Allison, M. A., Creager, M. A., Diehm, C., Fowkes F. G., Hiatt, W. R., Jönsson, B., Lacroix, P., Marin, B., McDermott, M. M., Norgren, L., Pande, R. L., Preux, P. M., Stoffers, H. E., Treat-Jacobson, D. (2012). Measurement and interpretation of the ankle-brachial index: A scientific statement from the American Heart Association. Circulation, 126, 2890-2909.

Aboyans, V., Ho, E., Denenberg, J. O., Ho, L. A., Natarajan, L., Criqui, M. H. (2008). The association between elevated ankle systolic pressures and peripheral occlusive arterial disease in diabetic and nondiabetic subjects. $J$. Vasc. Surg., 48, 1197-1203.

Adam, D. J., Beard, J. D., Cleveland, T., Bell, J., Bradbury, A. W., Forbes, J. F., Fowkes, F. G., Gillepsie, I., Ruckley, C. V., Raab, G., Storkey, H.; BASIL trial participants. (2005). Bypass versus angioplasty in severe ischaemia of the leg (BASIL): multicentre, randomised controlled trial. Lancet, 366, 1925-1934.

Antoniou, G. A., Chalmers, N., Georgiadis, G. S., Lazarides, M. K., Antoniou, S. A., Serracino-Inglott, F., Smyth, J. V., Murray, D. (2013). A meta-analysis of endovascular versus surgical reconstruction of femoropopliteal arterial disease. J. Vasc. Surg., 57, 242-253.

Collins, R., Cranny, G., Burch, J., Aguiar-Ibáñez, R., Craig, D., Wright, K., Berry, E., Gough, M., Kleijnen, J., Westwood, M. (2007). A systematic review of duplex ultrasound, magnetic resonance angiography and computed tomography angiography for the diagnosis and assessment of symptomatic, lower limb peripheral arterial disease. Health Technol. Assess., 11, $1-184$.

Criqui, M. H., Aboyans, V. (2015). Epidemiology of peripheral artery disease. Circ. Res., 116, 1509-1526.

Criqui, M. H., McClelland, R. L., McDermott, M. M., Allison, M. A., Blumenthal, R. S., Aboyans, V., Ix, J. H., Burke, G. L., Liu, K., Shea, S. (2010). The ankle-brachial index and incident cardiovascular events in the MESA. J. Amer. Coll. Cardiol., 56, 1506-1512.

Dormandy, J. A., Rutherford, R. B. (2000). Management of peripheral arterial disease. TransAtlantic Inter-Society Consensus (TASC). Eur. J. Vasc. Endovasc. Surg., 19, Suppl. A, 250 pp.

Eiberg, J. P., Grønvall Rasmussen, J. B., Hansen, M. A., Schroeder, T. V. (2010). Duplex Ultrasound scanning of peripheral arterial disease of the lower limb. Eur. J. Vasc. Endovasc. Surg., 40, 507-512.

Fowkes, F. G., Rudan, D., Rudan, I., Aboyans, V., Denenberg, J. O., McDermott, M. M., Norman, P. E., Sampson, U. K., Williams, L. J., Mensah, G. A., Criqui, M. H. (2013). Comparison of global estimates of prevalence and risk factors for peripheral artery disease in 2000 and 2010: a systematic review and analysis. Lancet, 382, 1329-1340.

Hooi, J. D., Kester, A. D., Stoffers, H. E., Overdijk, M. M., van Ree, J. W., Knottnerus, J. A. (2001). Incidence of and risk factors for asymptomatic peripheral arterial occlusive disease: A longitudinal study. Amer. J. Epidemiol., 153, 666-672.

Jaff, M. R., White, C. J., Hiatt, W. R., Fowkes, G. R., Dormandy, J., Razavi, M., Reekers, J., Norgren, L. (2015). An update on methods for revascularization and expansion of the TASC Lesion Classification to include below-the-knee arteries: A supplement to the Inter-Society Consensus for the Management of Peripheral Arterial Disease (TASC II). Ann. Vasc. Dis., 8 (4), 343-357.

Krievins, D., Savlovskis, J., Ezite, N., Hill, A., Kisis, K., Gedins, M., Zellans, E., Holden, A. (2018). The DETOUR procedure: No more need for conventional bypass surgery? J. Cardiovasc. Surg., 59 (2), 172-177.

McQuade, K., Gable, D., Pearl, G., Theune, B., Black, S. (2010). Four-year randomized prospective comparison of percutaneous ePTFE/Nitinol self-expanding stent graft versus prosthetic femoral-popliteal bypass in the treatment of superficial femoral artery occlusive disease. J. Vasc. Surg., 52, $584-591$. 
Rutherford, R. B. (Ed.) (2005). Vascular Surgery. Sixth edition. Elsevier Saunders. 2502 pp. (Chapter 6. Standardized Reporting Practices, p. 43).

Sobieszczyk, P., Eisenhauer, A. (2013). Management of patients after endovascular interventions for peripheral artery disease. Circulation, 128, 749-757.

Surowiec, S. M., Davies, M. G., Eberly, S. W., Rhodes, J. M., Illig, K. A., Shortell, C. K., Lee, D. E., Waldman, D. L., Green, R. M. (2005). Percutaneous angioplasty and stenting of the superficial femoral artery. $J$. Vasc. Surg., 41, 259-278.

Van Hattum, E. S., Tangelder, M. J. D., Lawson, J. A., Moll, F. L., Algra, A. (2011). The quality of life in patients after peripheral bypass surgery deteriorates at long-term follow-up. J. Vasc. Surg., 53 (3), 643-650.
Vlachopoulos, C., Xaplanteris, P., Aboyans, V., Brodmann, M., Cífková, R., Cosentino, F., De Carlo, M., Gallino, A., Landmesser, U., Laurent, S., Lekakis, J., Mikhailidis, D. P., Naka, K. K., Protogerou, A. D., Rizzoni, D., Schmidt-Trucksäss, A., Van Bortel, L., Weber, T., Yamashina, A., Zimlichman, R., Boutouyrie, P., Cockcroft, J., O'Rourke, M., Park, J. B., Schillaci, G., Sillesen, H., Townsend, R. R. (2015). The role of vascular biomarkers for primary and secondary prevention. Atherosclerosis, 241, 507-532.

Winter-Warnars, H., van der Graaf, Y., Mali, W. (1996). Inter-observer variation in duplex sonographic scanning in the femoropopliteal tract. J. Ultrasound Med., 15 (6), 321-328.

Xu, D., Zou, L., Xing, Y., Hou, L., Wei, Y., Zhang, J., Qiao, Y., Hu, D., Xu, Y., Li, J., Ma, Y. (2013). Diagnostic value of ankle-brachial index in peripheral arterial disease: A meta-analysis. Can. J. Cardiol., 29, 492-498.

Received 19 February 2019

Accepted in the final form 17 July 2019

\section{PQ ŠUNTĒŠANAS REZULTĀTU IZVĒRTĒŠANA AR ULTRASONODOPLEROGRĀFIJU}

Pacientiem ar perifērisko artēriju slimību (PAS) ir būtiski samazināti dzīves kvalitātes rādītāji. Hroniska apakšējo ekstremitāšu išēmija, ko izraisa infraingvinālo artēriju aterosklerotiski slēgumi, ir viens no biežākajiem invaliditātes cēloṇiem smēkētājiem vecumā virs 50 gadiem. Vēsturiski šì patoloğija tika ārstēta, izmantojot atvērtu ķirurğisku šuntēšanu. Mazinvazīvas endovaskularas revaskularizācijas metodes bija pieejamas īsāku asinsvadu slēgumu ārstēšanā, savukārt garākiem slēgumiem šādu metožu trūkst. Pilnībā endovaskulāra transvenoza femoropopliteāla šuntēšana ( $P Q$ Bypass), kas paredzēta garu ciskas artērijas oklūziju ārstēšanai, ieviesta nesen. Pētījuma mērkis bija novērtēt ultrasonodoplerogrāfiju (USD) kā izmeklēšanas metodi, ar kuru varētu sekot PQ procedūras rezultātiem. Klīniskais pētījums veikts P. Stradiṇa Klīniskajā universitātes slimnīcā. USD ārstěšanā izmantotajām artērijām un vēnām veica divi neatkarīgi speciālisti — pirms procedūras, 30 dienas, 6 mēnešus un 12 mēnešu attālajā periodā. Potītes-augšdelma indekss (PAI) tika noteikts visas vizītēs. Pētījumā iekḷauti 35 pacienti (35 kājas) kuri tika ārstēti, izmantojot PQ šuntēšanu. Vidējais pacientu vecums bija 63,6 gadi (no 50 līdz 87 gadiem). PQ rezultātu kontrole veikta visiem pacientiem visās vizītēs. USD rezultātu nobīde starp diviem radiologiem bija pieḷaujamās standarta robežās. Divpadsmit mēnešus pēc PQ procedūras 28 (80,0\%) PQ stenti joprojām funkcionēja bez stenozes pazīmēm USD, bet septiņos (20,0\%) gadījumos atklāta dažādas pakāpes darbības traucējumi stentā. PQ stenta oklūzija diagnosticēta pieciem pacientiem $(14,3 \%)$ - vienam $(2,9 \%)$ pirmā mēneša kontroles vizìtē, trim $(8,6 \%)$ sestā mēneša un vienam $(2,9 \%)$, attiecīgi 12 . mēneša vizìtē. PQ stenta proksimālā savienojuma stenoze atklāta vienam pacientam $(2,9 \%)$ sešu mēnešu kontroles vizìtē bet distālā savienojuma stenoze vienam pacientam (2,9\%) divpadsmit mēnešu kontroles vizītē. Neraugoties uz PQ šunta slēgumu, kas tika diagnosticêts ar USD, diviem pacientiem netika atrastas nopietnas PAI izmaiṇas. USD ir uzticama metode PQ procedūras rezultātu izvērtēšanā, un tai piemīt augstāka jutība nekā PAI, īpaši asimptomātiskas PQ stenta stenozes gadījumā. Regulāra un savlaicīga USD izmantošana pēcoperācijas periodā nodrošina savlaicīgu potenciālo komplikāciju atklāšanu un efektīvu ārstēšanu. 